\title{
PENENTUAN NILAI PREMI ASURANSI PERTANIAN BERBASIS INDEKS SUHU PERMUKAAN MENGGUNAKAN METODE BURN ANALYSIS
}

\author{
A.A Dwi Marsita Anggraeni ${ }^{1 \S}$, Komang Dharmawan ${ }^{2}$, Desak Putu Eka Nilakusmawati ${ }^{3}$ \\ ${ }^{1}$ Program Studi Matematika, Fakultas MIPA - Universitas Udayana [Email: aadwimarsita@gmail.com] \\ ${ }^{2}$ Program Studi Matematika, Fakultas MIPA - Universitas Udayana [Email: k.dharmawan@gmail.com] \\ ${ }^{3}$ Program Studi Matematika, Fakultas MIPA - Universitas Udayana [Email: nilakusmawati@unud.ac.id] \\ ${ }^{\S}$ Corresponding Author
}

\begin{abstract}
Temperature is an important factor in the production of agricultural commodities. For this reason, goverments needs to protect farmers in order to continue their farming. Climate-based agricultural insurance is an alternative to climate-related risk management. Insurance premium is given when the temperature index lower than the pre determined trigger index. The purpose of this study is to determine the stages and assumptions in determining the value of agricultural insurance premiums based on surface temperature index on cocoa commodities using the method of burn analysis. The temperature index was determined using the burn analysis method with the temperature as the climate parameter. Trigger values are determined based on long run times. In this paper, the result is that when the temperature index lower than the determined trigger value, trigger payments as much as Rp.10.931.960,40 / Ha based on trigger index as many $26.145^{\circ} \mathrm{C}$, so amount of premium payment equals $R p 215.776$.
\end{abstract}

Keywords: Agricultural Insurance, Burn Analysis, Put Cash or Nothing Options, Temperature Index

\section{PENDAHULUAN}

Negara Indonesia merupakan negara agraris yang artinya sektor pertanian memegang peranan penting dari keseluruhan perekonomian nasional (Putri et al, 2016). Pertanian berperan penting terhadap ketahanan pangan sebagai sumber mata pencaharian jutaan petani dengan berbagai keterbatasan. Namun, usaha pada sektor pertanian dipandang sebagai usaha yang berisiko tinggi terhadap kerugian. Faktor risiko kerugian yang diamati dalam penelitian ini dilihat dari pengaruh dinamika alam. Untuk itu, diperlukan perlindungan bagi petani agar dapat menangani risiko gagal panen yang dalam penelitian ini disebabkan oleh perubahan suhu permukaan.

Salah satu upaya perlindungan yang diberikan kepada petani adalah asuransi pertanian berbasis indeks suhu permukaan. Suhu permukaan adalah salah satu faktor penting lingkungan dan sangat berpengaruh pada proses fisiologi dari pertumbuhan tanaman (Afoakwa et al., 2013).

Sebelumnya penelitian terkait asuransi pertanian telah dilakukan oleh Intan et al., (2017) dan Suarjana et al., (2017) berbasis indeks harga internasional pada komoditas kopi yang masing-masing menggunakan metode mean reversion dengan lompatan dan metode black-scholes. Diperoleh hasil nilai premi yang dihasilkan dipengaruhi nilai trigger yang berbeda-beda, semakin besar nilai trigger yang diperoleh maka nilai premi yang harus dibayarkan juga semakain besar. Hal ini juga serupa dengan penelitian yang dilakukan oleh Putri et al, (2016) yang berbasis indeks curah hujan menggunakan metode black-scholes, nilai trigger yang dihasilkan didasarkan pada data historis indeks iklim yang digunakan, dan memperoleh nilai premi yang berbeda-beda.

Menurut Dharmawan et al., (2016) 
Asuransi diberikan pada usaha tani untuk melindungi petani dari risiko penurunan harga di pasar, khususnya untuk komoditas pertanian yang dijual di pasar modal seperti kopi, kedelai, kelapa sawit, cengkeh, dan lainnya. Sehingga penulis tertarik melakukan penelitian yang bertujuan untuk mengetahui perhitungan nilai premi asuransi pertanian berbasis indeks suhu permukaan menggunakan metode burn analysis dan mengetahui nilai premi yang fair bagi kedua belah pihak baik tertanggung maupun penanggung.

Menurut Undang-Undang Nomor 19 Tahun 2013 tentang Perlindungan dan Pemberdayaan Petani Pasal 30 ayat (1),"Pemerintah dan Pemerintah Daerah sesuai dengan kewenangannya berkewajiban melindungi usaha tani yang dilakukan oleh petani dalam bentuk asuransi pertanian". Salah satu asuransi yang dikembangkan saat ini adalah asuransi berbasis indeks.

Asuransi berbasis indeks merupakan bagian dari asuransi parametrik. Dalam sistem ini yang diasuransikan bukan tanaman, melainkan indeks iklim yang dalam penelitian ini digunakan adalah suhu permukaan. Dengan pemodelan indeks suhu yang tepat, tertanggung dapat menilai sifat distribusi pembayaran kontrak dan menentukan apakah kontrak tersebut memberikan perlindungan yang diharapkan (Jewson et al., 2005).

Hal terpenting dalam penilaian kontrak adalah penentuan biaya premi secara "fair" yang ditetapkan oleh perusahaan asuransi. Penentuan nilai premi dalam penelitian ini berdasarkan pada nilai trigger berbeda-beda yang ditentukan menggunakan metode burn analysis. Selanjutnya untuk mengetahui besarnya nilai premi yang harus dibayarkan maka digunakan opsi put tipe cash or nothing sebagai penentu nilai premi asuransi berbasis indeks suhu permukaan.

Opsi merupakan suatu kontrak atau perjanjian yang memberikan hak bukan kewajiban kepada pemegang kontrak untuk membeli atau menjual suatu asset induk (underlying asset) dengan indeks yang telah disepakati pada saat atau sebelum jatuh tempo
(Dharmawan et al., 2016). Terdapat banyak metode yang dapat dipakai untuk menentukan nilai kontrak opsi, salah satunya adalah metode Black-Scholes, yang diformulasikan sebagai berikut:

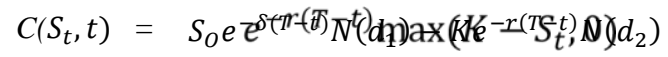

$$
\begin{aligned}
& P\left(S_{t}, t\right)=K e^{-\delta(T-t)} N\left(-d_{2}\right)-S_{0} e^{-r(T-t)} N\left(-d_{1}\right)(2)
\end{aligned}
$$

dengan:

$$
\begin{aligned}
& d_{1}=\frac{\ln \left(\frac{S_{0}}{K}\right)+\left(r-\delta+\frac{\sigma^{2}}{2}\right)(T-t)}{\sigma \sqrt{T-t}}, \\
& d_{2}=\frac{\ln \left(\frac{S_{0}}{K}\right)+\left(r-\delta-\frac{\sigma^{2}}{2}\right)(T-t)}{\sigma \sqrt{T-t}} .
\end{aligned}
$$

Pemilik kontrak opsi put cash or nothing akan menerima sejumlah $\gamma$ rupiah saat kontrak jatuh tempo saat nilai $S_{t}<\mathrm{K}$, atau akan menerima 0 rupiah (tidak menerima apapun) saat $S_{t} \geq K$. Pada opsi put cash or nothing fungsi payoff atau reward dari kontrak opsi yang didefinisikan dalam persamaan berikut:

$$
\gamma=e^{-r(T-t)} \max \left(K-S_{t}, 0\right)
$$

Dengan $\mathrm{S}_{\mathrm{t}}$ adalah harga komoditas pada waktu ke-t, $\mathrm{K}$ adalah trigger, $\mathrm{r}$ adalah suku bunga majemuk pada interval (T-t).

Nilai trigger pada penelitian ini dihitung berdasarkan hasil simulasi indeks suhu permukaan harian selama sepuluh tahun menggunakan metode burn analysis. Misalkan pembayaran sekaligus dari kontrak asuransi pertanian adalah $\mathrm{P}$, maka nilai premi asuransi pertanian berbasis indeks suhu permukaan dapat dihitung dengan formula:

$$
\text { Premi }=\mathrm{P} e^{-r(T-t)} N\left(-d_{2}\right) \text {. }
$$

Metode burn analysis dikembangkan oleh IRI Colombia University. Metode ini digunakan apabila di lokasi penelitian hanya tersedia salah satu data iklim. Menurut Jewson et al. (2005) metode burn analysis memiliki beberapa keuntungan yaitu diasumsikan data yang 
digunakan berdasarkan data historis secara lengkap pada setiap periode untuk menganalisis risiko.

Selain itu metode burn analysis memberikan indikasi pertama yang berguna dan intuitif tentang rata-rata dan hasil yang terjadi pada kejadian cuaca serta dampak yang dialami dalam segi finansial.

Untuk menentukan indeks rata-rata dari suhu permukaan rata-rata dapat digunakan formula sebagai berikut:

$$
\overline{T_{l}}=\frac{1}{N_{d}} \sum_{i=1}^{N_{d}} t_{i}
$$

\section{METODE PENELITIAN}

\subsection{Sumber Data}

Sumber data dalam penelitian ini menggunakan data sekunder yang diperoleh dari Dinas Perkebunan Provinsi Bali dan BMKG (Badan Meteorologi, Klimatologi dan Geofisika) Provinsi Bali. Data tersebut merupakan data triwulan produksi kakao Kabupaten Jembrana dan data suhu permukaan rata-rata harian Kabupaten Jembrana selama sepuluh tahun mulai tahun 2008-2017 yang dibuah kedalam triwulan.

\subsection{Jenis Data}

Data yang digunakan dalam penelitian ini merupakan data kuantitatif yaitu data rata-rata triwulan produksi kakao di Kabupaten Jembrana yang diperoleh dari Dinas perkebunan Provinsi Bali dan data harian suhu permukaan rata-rata di Kabupaten Jembrana.

\subsection{Metode Analisis}

Adapun tahapan-tahapan ilmiah dalam analisis data yang dilakukan dalam penelitian ini adalah sebagai berikut:

1. Mengumpulkan data triwulan rata-rata produksi kakao di Kabupaten Jembrana dan data harian suhu permukaan rata-rata di Kabupaten Jembrana selama sepuluh tahun dari tahun 2008 sampai dengan tahun 2017.

2. Untuk mengetahui keterkaitan antara suhu permukaan terhadap produksi komoditas kakao, maka dilakukan analisis korelasi antara suhu permukaan dengan produksi rata-rata tanaman kakao di Kabupaten Jembrana. Selanjutnya, menentukan indeks suhu permukaan sebagai nilai trigger yang diasuransikan menggunakan metode Burn Analysis yang dikembangkan oleh Jewson et al., (2005) adalah sebagai berikut:

a. Menghitung suhu permukaan rata-rata dasarian pada periode yang akan diasuransikan (indeks window).

b. Menghitung besarnya cap dan total suhu permukaan rata-rata dasarian yang disesuaikan. Nilai cap merepresentasikan nilai rata-rata maksimum suhu permukaan yang dihitung untuk setiap periode sepuluh hari (IRI, 2010).

c. Menghitung suhu permukaan rata-rata total yang disesuaikan selama setahun.

d. Menentukan nilai trigger $(K)$ berdasarkan hasil perhitungan menggunakan metode burn analysis.

e. Melakukan Uji Lognormalitas data nilai trigger $(\mathrm{K})$.

Setelah memperoleh nilai trigger selanjutnya ditentukan besarnya premi asuransi yang dibayarkan oleh pihak tertanggung sebagai berikut:

3. Menentukan nilai pertanggungan $(\mathrm{P})$ asuransi pertanian berdasarkan biaya variabel dan biaya tetap tanaman kakao.

4. Menghitung nilai premi asuransi pertanian dengan opsi put cash or nothing menggunakan persamaan (4).

\section{HASIL DAN PEMBAHASAN}

\subsection{Identifikasi Data Penelitian}

Data suhu permukaan rata-rata harian yang diperoleh dari BMKG Wilayah III Denpasar dan data produksi rata-rata triwulan komoditas kakao yang dieroleh dari Dinas Perkebunan Provinsi Bali di Kabupaten Jembrana periode Januari 2008 sampai dengan Desember 2017 yang disajikan dalam bentuk plot suhu permukaan harian, plot suhu permukaan triwulan, dan plot produksi rata-rata triwulan kakao pada Gambar (a) dan (b). 

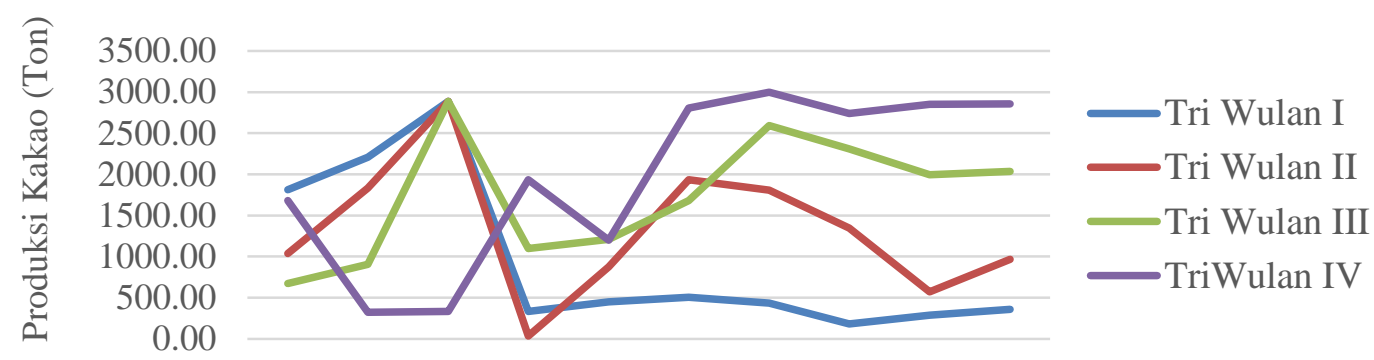

2008200920102011201220132014201520162017

Tahun

(a). Plot Suhu Permukaan Triwulan di Kabupaten Jembrana (2008-2017)

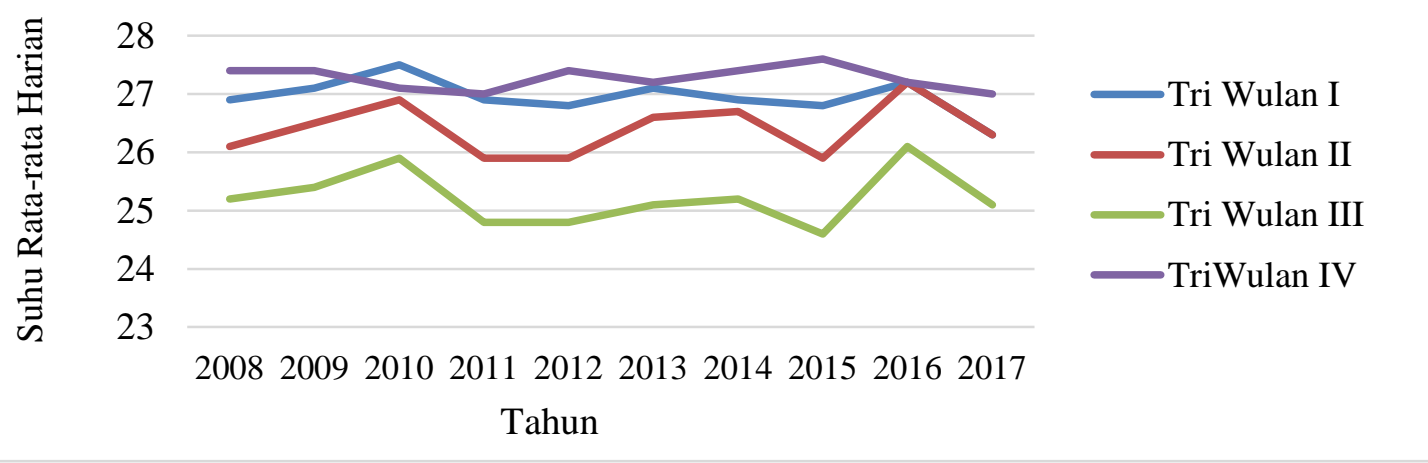

(b). Plot Produksi Kakao di Kabupaten Jembrana (2008-2017)

Berdasarkan Gambar (a) dan Gambar (b) terlihat bahwa terjadinya fluktuasi setiap tahunnya mulai dari tahun 2008 sampai dengan 2017. Hal ini mengakibatkan ketidakpastian

\subsection{Keterkaitan Suhu Permukaan dengan Produksi Komoditas Kakao di Kabupaten Jembrana}

Hubungan yang erat antara suhu permukaan rata-rata dan produksi rata-rata komoditas kakao menjadi jaminan bagi perusahaan asuransi dalam mengasuransikan risiko fluktuasi suhu permukaan rata-rata. Menurut Sugiyono (2012) koefisien korelasi Pearson Product Moment dapat dirumuskan sebagai berikut:

$r_{x y}=\frac{n \sum x_{i} y_{i}-\left(\sum x_{i}\right) \cdot\left(\sum y_{i}\right)}{\sqrt{\left(n \sum x_{i}^{2}-\left(x_{i}\right)^{2}\right) \cdot\left(n \sum y_{i}^{2}-\left(y_{i}\right)^{2}\right)}}$

Berdasarkan persamaan di atas diperoleh hasil perhitungan koefisien korelasi yang disajikan pada Tabel 1.

Tabel 1. Koefisien Korelasi Suhu Permukaan hasil pertanian kakao yang diperoleh setiap musim panen dan juga berpengaruh pada pendapatan petani tersebut.

Terhadap Produksi Kakao

\begin{tabular}{|c|c|c|c|c|}
\hline Produksi Kakao & \multicolumn{4}{|c|}{ Suhu Permukaan } \\
\hline & Suhu I & Suhu II & Suhu III & Suhu IV \\
\hline Triwulan I & 0,585 & 0,518 & 0,191 & $-0,475$ \\
\hline Triwulan II & 0,265 & 0,441 & 0,497 & 0,049 \\
\hline Triwulan III & 0,485 & 0,337 & 0,303 & $-0,221$ \\
\hline Triwulan IV & $-0,020$ & 0,157 & $-0,097$ & $-0,018$ \\
\hline
\end{tabular}

Sumber: Data diolah, 2018

Hasil perhitungan korelasi Pearson product moment menunjukkan suhu permukaan pada triwulan I memiliki koefisien korelasi terkuat yaitu 0,585. Koefisien korelasi (r) bernilai positif menunjukkan keeratan hubungan antara variabel $x$ dan variabel $y$ yang searah hal ini berarti semakin meningkat suhu permukaan ratarata maka nilai dari produksi rata-rata kakao semakin meningkat. 


\subsection{Menentukan Nilai Statistik Deskriptif Data}

Nilai statistik deskriptif dapat ditentukan dengan memanfaatkan data suhu permukaan harian terpilih yang disajikan pada Tabel 2 .

Tabel 2. Nilai Statistik Deskriptif Suhu Permukaan Terpilih

\begin{tabular}{cc}
\hline \multicolumn{2}{c}{ Statistik Deskriptif } \\
\hline Mean & $-0,00002$ \\
Varian & 0,00108 \\
\hline Standar Deviasi & 0,0081475 \\
\hline Skwenes & $-0,16266$ \\
Kurtosis & 0,53467 \\
\hline
\end{tabular}

Sumber: Data diolah, 2018

Hasil perhitungan nilai statistik deskriptif data suhu permukaan terpilih diperoleh nilai skwenes sebesar -0,16266 (bernilai negatif) yang artinya data suhu permukaan terpilih mengalami kemencengan ke kiri. Selanjutnya diperoleh nilai kurtosis data suhu permukaan terpilih bernilai kurang dari 3 yaitu sebesar 0,53467 yang menandakan data suhu permukaan terpilih tidak terdapat ekor gemuk (fat tail) atau tidak terdapat nilai ekstrim pada data.

\subsection{Penentuan Indeks Suhu Permukaan Yang Diasuransikan Menggunakan Metode Burn Analysis}

Selanjutnya, penentuan indeks suhu permukaan sebagai nilai trigger yang diasuransikan menggunakan metode Burn Analysis yang dikembangkan oleh Jewson et al., (2005) diperoleh sesuai dengan asumsi-asumsi berikut ini:

1. Index window (indeks yang diasuransikan) dipilih berdasarkan koefisien korelasi paling kuat antara suhu permukaan dengan produksi kakao.

2. Nilai cap yang digunakan diperoleh berdasarkan rata-rata dari suhu permukaan terpilih yaitu sebesar 27 Celcius.

Nilai cap merepresentasikan rata-rata maksimum suhu permukaan yang dihitung untuk setiap periode sepuluh hari (dasarian).

3. Menentukan suhu permukaan yang disesuiakan (adjusted temperature) berdasarkan nilai cap. Dengan asumsi berikut:

- Jika rata-rata setiap dasarian selama periode terpilih lebih dari nilai cap maka nilai yang disesuaikan bernilai sama dengan nilai cap.

- Jika rata-rata setiap dasarian selama periode terpilih kurang dari nilai cap maka nilai yang disesuaikan menggunakan nilai ratarata suhu permukaan dasarian tersebut.

4. Hasil perhitungan rata-rata total suhu permukaan untuk setiap tahun yang disusun berdasarkan jumlah indeks terkecil sampai dengan terbesar disajikan pada Tabel 3.

Tabel 3. Rata-rata Total Suhu Permukaan Setiap Periode Tahun

\begin{tabular}{|c|c|}
\hline Tahun & Indeks Suhu Permukaan $\left({ }^{\circ} \mathrm{C}\right)$ \\
\hline 2014 & 26,1 \\
\hline 2013 & 26,2 \\
\hline 2015 & 26,2 \\
\hline 2009 & 26,3 \\
\hline 2011 & 26,3 \\
\hline 2017 & 26,3 \\
\hline 2008 & 26,5 \\
\hline 2010 & 26,5 \\
\hline 2012 & 26,5 \\
\hline 2016 & 26,6 \\
\hline
\end{tabular}

Sumber: Data diolah, 2018

Pada Tabel 3 terlihat nilai trigger yang dihasilkan menggunakan metode burn analysis memberikan gambaran awal dalam menentukan nilai premi asuransi yang dibayarakan.

5. Menentukan nilai trigger $(\mathrm{K})$ yang didapat dari persentil data hasil simulasi suhu permukaan rata-rata selama sepuluh tahun. Pada Tabel 4. disajikan hasil perhitungan trigger sesuai persentil dan indeks suhu permukaannya.

Pada Tabel 4. diperoleh nilai trigger yang berbeda-beda diberikan sebagai alternatif atau pilihan yang dapat diambil oleh petani atau pihak tertanggung (Suarjana et al., 2017).

6. 
Tabel 4. Nilai Trigger (K) Berdasarkan Simulasi Suhu Permukaan Rata-rata Harian Selama 10 Tahun

\begin{tabular}{cc}
\hline Persentil ke- & Trigger $(\mathrm{K}){ }^{\circ} \mathrm{C}$ \\
\hline 5 & 26,145 \\
10 & 26,19 \\
15 & 26,2 \\
20 & 26,2 \\
25 & 26,225 \\
30 & 26,27 \\
\hline
\end{tabular}

Sumber: Data diolah, 2018

\subsection{Uji Lognormalitas Indeks Suhu Permukaan Rata-rata}

Uji lognormalitas digunakan untuk mengetahui populasi data berdistribusi lognormal atau tidak. Dalam penelitian ini menggunakan Uji Anderson-Darling dengan taraf signifikasi $\alpha=5 \%$ dengan Hipotesis yang diajukan adalah sebagai berikut:

$H_{0}$ : Data simulasi triwulan I berdistribusi lognormal

$H_{1}$ : Data simulasi triwulan I tidak berdistribusi lognormal

Tabel 5. Hasil Uji Lognormalitas dengan Anderson-Darling

\begin{tabular}{|c|c|c|c|}
\hline $\mathbf{N}$ & Mean & St-Dev & $\boldsymbol{p}$-value \\
\hline 10 & 26,35 & 0,1650 & 0,207 \\
\hline
\end{tabular}

Sumber: Data diolah, 2018

Tabel 5. memperlihatkan hasil uji lognormalitas menggunakan Anderson-Darling untuk 10 data simulasi suhu permukaan rata-rata komoditas kakao dengan standar deviasi 0,1650 dan nilai $p-$ value sebesar 0,207 . Karena nilai $p$-value $>\alpha=5 \%$ dengan demikian keputusan yang diambil ialah tidak cukup bukti untuk menolak hipotesis nol $\left(H_{0}\right)$ yang artinya data indeks suhu permukaan yang diasuransikan berdistribusi lognormal.

\subsection{Penentuan Nilai Pertanggungan (P)}

Tahapan selanjutnya menentukan nilai pertanggungan $(\mathrm{P})$ asuransi pertanian berdasarkan pada biaya variabel dan biaya tetap produksi kakao meliputi biaya benih kakao, pupuk (pupuk organik dan pupuk NPK), biaya tenaga kerja, penyusutan alat, pemasaran dan PBB. Berdasarkan biaya variabel dan biaya tetap tersebut maka petani tersebut akan memperoleh nilai pertanggungan pada produksi kakao sebesar Rp.10.931.960/Ha.

\subsection{Menentukan Nilai Premi Asuransi Pertanian Berbasis Indeks Suhu Permukaan}

Selanjutnya ialah tahapan menentukan nilai premi asuransi pertanian menggunakan opsi put cash or nothing. Implementasi perhitungan premi dengan penyesuaian diantaranya $S_{0}$ adalah indeks suhu permukaan dasar yang diperoleh dari hasil simulasi menggunakan metode burn analysis yaitu $26,6^{\circ} \mathrm{C} . \sigma=0,008148$, standar deviasi suhu permukaan terpilih dihitung dengan bantuan software Microsoft Excel 2013. K adalah nilai trigger yang diperoleh dari persentil data hasil simulasi komoditas kakao berbasis indeks suhu permukaan selama 10 tahun. Suku bunga bebas risiko pada penenlitian ini diasumsikan konstan sebesar 6,5\% dan $\delta$ adalah deviden yang diasumsikan 0 . Berikut akan ditampilkan hasil perhitungan nilai premi asuransi pertanian berbasis indeks suhu permukaan dengan trigger yang berbeda-beda pada Tabel 6 .

Tabel 6. Hasil Perhitungan Nilai Premi Asuransi dengan Trigger yang berbeda

\begin{tabular}{ccc}
\hline $\begin{array}{c}\text { Persentil } \\
\text { ke- }\end{array}$ & Trigger $(\mathrm{K})$ & $\begin{array}{c}\text { Nilai } \\
\text { Pertanggungan } \\
(\mathrm{Rp})\end{array}$ \\
\hline 5 & 26,145 & $10.931 .960,40$ \\
10 & 26,19 & $10.931 .960,40$ \\
15 & 26,2 & $10.931 .960,40$ \\
20 & 26,2 & $10.931 .960,40$ \\
25 & 26,225 & $10.931 .960,40$ \\
30 & 26,27 & $10.931 .960,40$ \\
\hline & & \\
\hline Premi $(\mathrm{Rp})$ & Persentase Premi $(\%)$ \\
\hline $215.776,63$ & & 1,97 \\
$277.182,69$ & 2,54 \\
$292.637,46$ & 2,68 \\
$292.637,46$ & 2,68 \\
$334.431,01$ & 3,06 \\
$421.872,96$ & 3,86 \\
\hline
\end{tabular}

Sumber: Data diolah, 2018 
Berdasarkan hasil perhitungan yang disajikan pada Tabel 6. menunjukkan bahwa adanya perbedaan nilai premi dari setiap nilai trigger yang digunakan. Dimana semakin besar nilai trigger maka semakin besar pula nilai premi yang harus dibayarkan oleh pembeli polis asuransi. Semakin tinggi nilai trigger tersebut, maka semakin besar peluang (probabilitas) terjadinya harga tersebut (Suarjana, 2017).

Berikut adalah contoh perhitungan premi asuransi pertanian komoditas kakao pada persentil ke- 5 dengan opsi put cash or nothing menggunakan metode black-scholes sebagai berikut:

$$
\begin{aligned}
& d_{1}=\frac{\ln \left(\frac{S_{0}}{K}\right)+\left(r+\frac{\sigma^{2}}{2}\right) t}{\sigma \sqrt{t}} \\
& =\frac{\ln \left(\frac{26,6^{\circ} \mathrm{C}}{26,145^{\circ} \mathrm{C}}\right)+\left(0,065+\frac{(0,008148)^{2}}{2}\right) 0,25}{0,008148 \times \sqrt{0,25}} \\
& d_{1}=2,056553904
\end{aligned}
$$

Maka nilai $d_{2}$ dapat dihitung sebagai berikut:

$d_{2}=d_{1}-\sigma \sqrt{t}$

$d_{2}=2,056553904-(0,008148 \sqrt{0,25)}$

$d_{2}=2,05248$

$N\left(-d_{2}\right)=0,97993849$

Berdasarkan hasil perhitungan fungsi distribusi kumulatif $d_{2}$ saat trigger sebesar 26,145 adalah sebesar 0,97993849, maka perhitungan premi yang harus dibayarkan menggunakan persamaan (4) adalah sebagai berikut :

Premi $=P e^{-r t} N\left(-d_{2}\right)$

$=$ Rp. $10.931 .960,40 \times e^{(-0,065 \times 0,25)} \times 0,97993849$

$$
=\text { Rp. } 215.776,63
$$

Menurut Dharmawan et al., (2016) perhitungan nilai premi asuransi menggunakan metode black-scholes dikatakan lebih fair. Hal ini karena perhitungan menggunakan metode black-scholes memberikan peluang risk neutral yang memperlihatkan keterbukaan dan keadilan bagi kedua belah pihak dalam membuat suatu kesepakatan kontrak pengalihan risiko (asuransi). Nilai premi asuransi pertanian untuk trigger yang berbeda-beda harus dibayarkan oleh pihak tertanggung (petani) satu kali selama musim panen yang dalam penelitian ini musim panen terjadi 3 kali dalam setahun. Pihak tertanggung berhak mendapatkan nilai pertanggungan apabila suhu permukaan jatuh dibawah nilai trigger yang telah disepakati, tanpa perlu adanya bukti kegagalan panen.

Pada penelitian ini diberikan lima pilihan besaran premi asuransi yang fair bagi pihak pemegang polis (petani) asuransi pertanian berbasis indeks suhu permukaan. Adapun besaran nilai premi tersebut berada pada persentil ke-5 sampai dengan persentil ke-30 dengan trigger yang berbeda-beda.

\section{KESIMPULAN DAN SARAN}

\section{Kesimpulan}

Perubahan suhu permukaan memiliki korelasi yang kuat terhadap peningkatan produksi komoditas kakao di Kabupaten Jembrana. Keterkaitan yang kuat digunakan sebagai jaminan bagi perusahan asuransi dalam pelaksanaan asuransi pertanian pada komoditas kakao berbasis suhu permukaan. Penentuan nilai trigger menggunakan metode burn analysis mengasumsikan data yang digunakan didasarkan pada data runut dari data historis obyek yang dipilih.

Penentuan nilai premi dengan opsi put cash or nothing menggunakan metode black-scholes memberikan penilaian premi yang fair. Hal ini karena perhitungan menggunakan metode blackscholes memberikan peluang risk neutral yang memperlihatkan keterbukaan dan keadilan bagi kedua belah pihak dalam membuat suatu kesepakatan pengalihan risiko (asuransi). Hasil perhitungan premi asuransi komoditas kakao berbasis indeks suhu permukaan diperoleh besaran premi dengan trigger yang berbedabeda. Pada penelitian ini ditawarkan lima pilihan premi asuransi yang dapat dibayarkan.

\section{Saran}

Adapun saran yang dapat disampaikan oleh penulis adalah untuk penentuan nilai premi asuransi berbasis indeks suhu permukaan agar penelitian selanjutnya dapat menggunakan metode lain seperti index modelling dan 
dynamical temperature index yang dapat meramalkan pola suhu permukaan dimasa yang akan datang dengan memanfaatkan distribusi dari data suhu permukaan tersebut.

\section{DAFTAR PUSTAKA}

Afoakwa, E. O. (2013). Cocoa Production and Processing Technology. New York: CRC Press.

Dharmawan, K., Widia, I W. dan Eswaryanti L.P.K.Y. 2016. Penerapan Metode Penilaian Kontrak Opsi dalam Penentuan Premi Asuransi Pertanian Berbasis Indeks Curah Hujan. Makalah Invited Speaker Pada Seminar Nasional Matematika XVIII Pekanbaru, Riau, 2-3 November 2016.

International Research Institute (US). 2010. Weather Index Insurance Education Tool (WIIET) dalam http://iri.colombia.edu/education/insuranceetol.

Jewson, S., Brix, A., \& Ziehmann, C. (2005 Weather Derivatives Valuation The Meteorological,Statistical, Financial and Mathematical Foundations. New York: Cambrigde University Press.

Lestari, I., Dharmawan, K., \& Nilakusmawati, D.P.E. (2017). Penentuan Nilai Premi Asuransi Pertanian Pada Komoditas Kopi Berbasis Harga Internasional Menggunakan Model Mean Reversion dengan Lompatan. E-Jurnal Matematika, Volume 6 No 4, hlm 253-259.

Putri, I. A., Dharmawan, K., \& Tastrawati, N. K. T. (2016). Perhitungan Premi Asuransi Pertanian Yang Berbasis Indeks Curah Hujan Menggunakan Metode Black-Scholes. E-Jurnal Matematika, Volume 6 No 2, hlm 161-167.

Suarjana, I. W., Widia, I. W., \& Dharmawan, K. (2017). Penentuan Nilai Kontrak Asuransi Usaha Tani Tanaman Kopi Arabika Berbasis Indeks Harga Internasional. Jurnal Beta (Biostem dan Teknik Pertanian), Volume 5 No 2.

Sugiyono. 2012. Metode Penelitian Kuantitatif Kualitatif dan R\&D. Penerbit Alfabeta. Bandung. 